\title{
Obrzęd rzymski, perski, portugalski, celtycki... i sarmacki. Kultury obce w historycznych egzemplach obyczajowych na przykładzie oracji weselnych
}

Małgorzata Trębska 


\section{Obrzęd rzymski, perski, portugalski, celtycki... i sarmacki. Kultury obce w historycznych egzemplach obyczajowych na przykładzie oracji weselnych}

$\mathrm{O}$ zdabianie progu domu glową zabitego smoka, wyciskanie piętna na czole, wysysanie krwi z naciętych opuszków palców, okładanie pięściami, a także spacery pod jarzmem, spożywanie rozciętego mieczem chleba, obrzucanie „fruktami palmowymi” i strojenie się w szparagi — opisy takich obyczajów różnych narodów i plemion znaleźć można w XVII- i XVIII-wiecznych tekstach oracji weselnych² i podręcznikach retoryki. Te drastyczne nierzadko deskrypcje pozornie niewiele maja wspólnego z podniosłym i panegirycznym charakterem uroczystości ślubnych, jednak staropolscy mówcy, chcąc zadziwić swych słuchaczy i skupić na sobie uwage audytorium, uciekali się do najrozmaitszych sposobów, do czego uprawniala ich teoria retoryczna.

Egzordium mowy należącej do rodzajı pokazowego (gemus demonstratimum), a więc także i weselnej, mogło być ukształtowane w sposób dość dowolny, zależnie od zdolności, upodobania i gustu mówcy ${ }^{3}$. W praktyce przemówienia wygłaszane przy oddawaniu panny lub dzię-

"W tym wypadku chodzi o .,frukta” palm daktylowych. nic zaś kokosowych.

- Zob. najnowsze publikacje czçściowo lub w całuści poświçcone oratorstwu weselncmu: K. Mroczek.

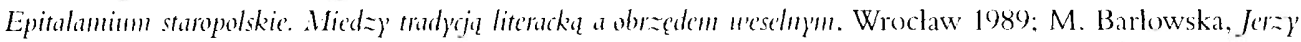

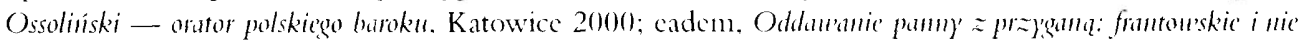

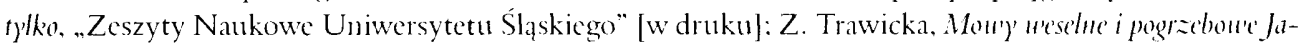

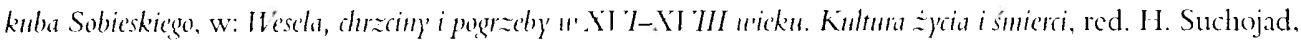

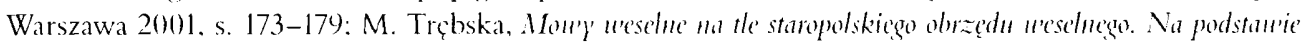

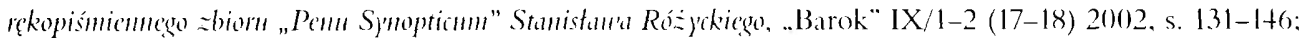

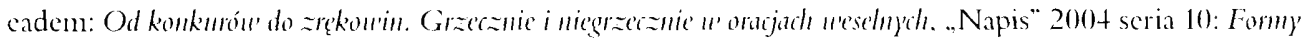
inormy' stosol'ności, s. 65-80.

${ }^{3}$ Zob. Arystoteles, Retoryka III. 1+1+b (Arystoteles, Retoryka. Retoryka dla . Aleksandra. Poetyka, tl., wst. i koment. H. Podbiclski, Warszawa 2004, s. 205). 
kowaniu za nią zaczynano ogólnymi rozważaniami na temat kondycji i powolania czlowieka czy zalet stanu malzeńskiego ${ }^{+}$. Mógł to być także enkomion panującego, jeśli ten był obecny przy ceremonii ${ }^{5}$, a nawet pochwala ustroju Rzeczypospolitej szlacheckiej ${ }^{6}$. Anonimowy autor rękopiśmiennego podręcznika retoryki Rhetorica Sarmatico Hymaeneo sacra zaleca tworzyć wstęp mowy weselnej towarzyszącej oddawaniu panny w sposób następujący: „Zaczyna się jakąś rozprawą o przyjaźni albo jakimś locus commmunis stosownym do tego rodzaju mów"7. Z kolei Samuel Wysocki, twórca XVIII-wiecznego kompendium zatytułowanego Orator Polonus, pisze: „Od jakiejś okoliczności, erudycji lub sentencji zaczyna się początek, i przechodzi się wreszcie do tematu owej mowy” "Należy postawić pytanie, co można uznać za „stosowną” okoliczność, erudycję lub sentencję? Zakres tematyczny przywoływanych egzemplów, których erudycje stanowią szczególną odmianę, jest bardzo szeroki. Mówca mial prawo opowiedzieć w zasadzie o każdym wydarzeniu historycznym lub mitologicznym", jeśli tylko umial znaleźć uzasadnienie dla jego przywolania i wkomponować przykład w tok wywodu bez naruszania spójności i logiki tekstu. Zasadniczo jednak przykłady były w pewien sposób, nierzadko bardzo luźny, związane z tematyką kojarzoną ze ślubem: z uczuciami (miłością, przyjaźnią, wiernością) lub $z$ atrybutami przekazywanymi w czasie ceremonii (wieńcem, pierścieniem, roztruchanem, czyli kielichem, lańcuchem lub naszyjnikiem, dzbanem i miednicą etc.). W ostatnim przypadku wystarczalo, aby w egzemplum znalazlo się jakiekolwiek nawiązanie do funkcji użytkowej, ksztaltu, barwy lub materiału, z którego zostal zrobiony ofiarowany przedmiot (okrąg, róża, złoto, klejnot). Wspominano więc o cesarzu Karolu V, który mial pierścień z wbudowanym zegarkiem, i o pierścieniu Pliniusza młodszego, na którym widniało wyobrażenie „poczwórnego cugu", i o kielichu jednego z królów francuskich ozdobionym wizerunkiem anioła trzymają-

+Zob. M. Barlowska, op. cit.; M. Trębska, Mon'y' "'e'se'lué..., passim.

'Przykladowo: oracje wyglaszanc przez Andrzcja Chryzostoma Zaluskiego w obecności Jana III Sobie-

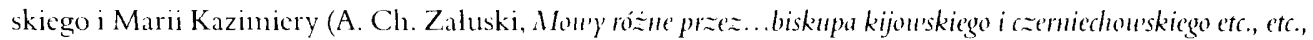

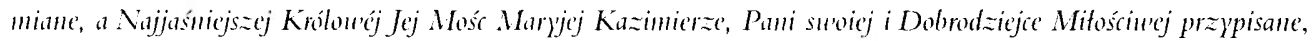
Warszawa 1690, i kolejne edycje zawierające te same oracje weselne: Kalisz 1702 i 1730).

"Przykładowo: mowa Stcfana Paca wygloszona na weschu Katarzyny Radziwillówny i Jerzego Illebowicza, zob. J. Ostrowski-Dancykowicz, Sucada polska i tacinska, albo miscellanea onatorskie, sejmowe, weselne',

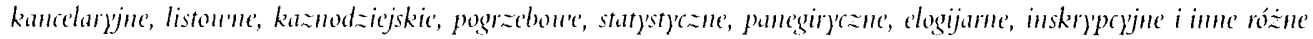

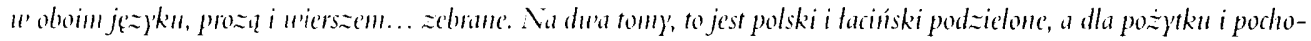

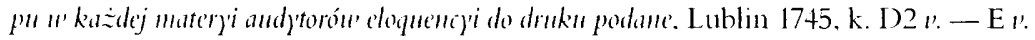

"Pracmittit(ar) aliquis discursus de amicitia ad aliquis locus commmmis huic generi orationmm accomodatus" — zob. reckopis Bibliotcki Zaktadu Narodowego im. Ossolińskich we Wroclawiu, sygn. Ossol. 1884: Rhetorica

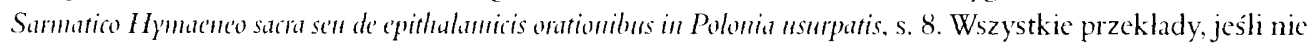
zaznaczono inaczej. pochodzą od autorki ninicjszego artykulu.

*..Id est dum primo ab aliqua circtumstantia, conditione vel se'tentria fomantur accessus, ac tandem descenditur ad materiam illins orationis" - zob. S. Wysocki, Otator Polonns primo aliquot instructionibus de comitiis, legationibus, militia, politia; deinde' occasionibns ibidem dicendi, modis, materiis, exemplis et smpplementis infonmatus..., Warszawa 1740, s. 726. "W tradycji antyczncj egzempla dziclone były na historycznc i poctyckic, wszystkic jednak musialy nosić

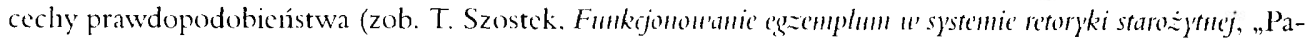
miçtrik Literacki” R. 87: 1996, z. 1, s. 48-49). 
cego lilię. Mówiono o Atalancie, która po zwyciężenin współzawodnika "glowę nu urzynała, a sicbie w wieniec stroiła" "10 o Kleopatrze, która rozpuszczała perły w winie, o upodobaniu króla polskiego Bolesława do noszenia na lańcuchu podobizny swego ojca, o symbolice medali bitych z okazji kolejnych ślubów Zygmunta III Wazy, albo o kochance, a następnie żonie Cyrusa, która, pamiętając o tym, że była niewolnicą, kazała na swojej koronie przedstawić mrówkę i pszczolę z inskrypcją: "Hoc exsto quod gesto”, co można przełożyć swobodnie: „Tym slynę, co czynię”, a co dawny czytelnik opatrzył w rękopisie komentarzem: „Praca korony się dorabia”"1. Stosownie do potrzeb przywoływano znane z historii antycznej lub nowożytnej albo z mitologii postaci władców, herosów, bogów rzymskich oraz greckich i ich kochanek lub wrogów etc. Lista możliwości jest zasadniczo niewyczerpana, tak jak nieskończona jest lista wybitnych osobistości historycznych czy ciekawych postaci literackich.

Obok czynów lub powiedzeń konkretnych osób!2 wspominano również o obyczajach różnych narodów i plemion. W tej grupie szczególnie interesujące są erudycje dotyczące obyczajowości weselnej. Wiele podręczników retoryki zawiera zestawienia „stosownych” przykładów tego typu. Wśród nich znajdujemy między innymi takie propozycje:

U Persów umiejąca panna rządzić poczwórnym cugicm sama sobie oblubieńca obieralat ${ }^{13}$;

U Rzymian podczas wesela podwoje u drzwi lanrami uwieszali ${ }^{14}$;

U Persów i Medów oblubienice z oblubieńcami prawe sobie podawają ręce ${ }^{15}$;

U Rzymian podczas wesela pod progiem kładziono zabitego smoka głowę".

Niektóre z cytowanych tu erudycji mają charakter bardzicj ogólny, inne dotyczą atrybutu lub tematu wskazującego na możliwość wykorzystania w mowie określonego typu gatunkowego. Przykładowo, przekazując roztruchan, orator mógłby popisać się znajomością następujących faktów:

U dawniejszych Francuzów na znak dożywotniej przyjaźni oblubienica oblubieńcowi przyszłenu wodę podawala ${ }^{17}$;

\footnotetext{
" S. Wysocki. op. cit., s. 749.

"Rękopis Biblioteki Uniwersyteckicj w Warszawic sygn. BUW 197: Mómra polski na akty' Hugte i niespordzie' u'anc opatromy's. 83: na k. tyt. data: 1703.

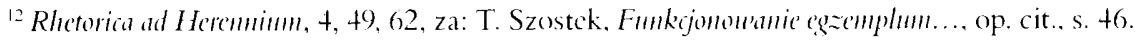

${ }^{13}$ Rps BUW 197. s. 80.

it Ibide'm, s. 83 .

15 Hidcm, s. 79): ten sam przyklad: S. Wysocki. op. cit., s. 748.

1. Rps BUW 197. s. 83-84.

${ }^{17}$ Ibidem. s. 88. Podobne w rękopisie Biblioteki Czartoryskich w Krakowie: ... Apud Gulathos inituri commubium ex eodem poculo bibehant" (rps BCzart. 1884, s. 12).
} 
U Galatów oblubieniec z oblubienicą z jednego roztruchana zażywali napoju ${ }^{18}$;

U Massilyjczyków na znak doźywotniej przyjaźni oblubienica swemu oblubieńcowi pełen roztruchan podawała".

Z kolei mówca oddający w imieniu kawalera wieniec mógł przytoczyć inne przykłady:

U Anglów pannę młodą wieńcem z kłosów uwitych koronowano²";

Palestyńczykowie oblubienice stroili w szaty kwiatami ozdobione ${ }^{21}$;

U Luzytańczyków oblubienice z samych tylko róż uwite wieńce nosiły²?.

Z kolei mówca ofiarowujący pannie pierścień mógł wykorzystać którąś z poniższych erudycji:

U Rzymian ślubny pierzcień był zelazny i bez zadnego drogiego kamienia, bo sama oblubienica klejnotem owego pierzcienia byla ${ }^{23}$;

U Rzymian żadnego zwierzęcia bogom nie ofiarowano, którego by się kapłan rzymski pierzcieniem nie dotknąl2+;

U Elamitów na znak dożywotniej przyjaźni serdeczne sobie ranili palce i krew z nich wysysali ${ }^{25}$.

Naturalnie każdy z tych przykładów mógł znaleźć zastosowanie w innym typie gatunkowyın oracji weselnych niż tu wskazany, zwłaszcza że autorzy kompendiów rzadko precyzują przeznaczenie podawanych przez siebie przykładów. Najczęściej grupująje ze względu na jeden z glównych komponentów (pierścień, woda, część ludzkiego ciała, zwierzę czworonogie lub element architektoniczny). Mówca ma zatem prawo do swobodnej decyzji, i może kierować się wlasnym wyczuciem i smakiem w doborze motywów i faktów.

Wybór erudycji to pierwszy krok, kolejny to wkomponowanie go w tok wywodu. Nie jest to zadanie bynajmniej latwe, zwłaszcza gdy chce się powiązać elementy dość odległe tematycznie.

\footnotetext{
${ }^{1 *}$ Rps BUW 197. s. 90.

"Ibidem, s. 90. Podobne w rpsic BCzart. 1884, s. 12: .A Apud Massilicnse's an sponsa phialam impletam porrexisset, ci mubebat".

In S. Wysocki, op. cit.

${ }^{21}$ Rps BUW 197, s. 85.

22 Ibide'm, s. 85. Także w zbiorze Wysockiego (loc. cit.) znajdujemy to samo egzemplum: „U Luzytanów w róży kwiat pannę mlodą strojono".

${ }^{23}$ Rps BUW 197. s. 79.

${ }^{2+}$ Ibidem. s. 80 .

${ }^{25}$ Ibide'm. s. 79
} 
Na weselu Jana Wielopolskiego i Marii Anny de la Grange d'Arquien, siostry Marii Kazimiery, w 1678 roku w imieniu pary królewskiej pannę oddawal Stanisław Jabłonowski, wojewoda ruski i hetman polny koronny ${ }^{26}$. On także wkomponowal w pochwalę ozdobnik erudycyjny:

Egiptianie, chcąc pokazać rodowitość domu jakiegoś, kupę papieru kładli, dając do wyrozumicnia, że sila by papieru wypisać potrzeba. Gidy ja przystępuję o zacności domu Jej Mości Panny mówić, tu by należało kupę papieru polożyć, bo i pamiętać tak siła, i mówić tak wiele, rzecz jest niepodobna ${ }^{27}$.

Nie jest tu oczywiście istotną kwestia, czy Egipcjanie używali papieru, czy może jednak był to papirus, ale sposób, w jaki Jabłonowski wykorzystuje egzemplum, a czyni to, znajdując najpprostszą analogię. Duża ilość, „kupa” papienu miała symbolizować obszemość pochwały. Znakomitość rodu Marii Anny wymaga tak dlugiego enkomionu, enumeracji tylu nazwisk, koligacji, urzędów i zaszczytów, że mówca chętnie skorzystałby z notatek, aby wspomóc pamięć. W rzeczy samej zalecenie panny mlodej, które formuluje Jabłonowski, jest niezwykle długie (nawet jak na standardy drugiej polowy XVII wieku), bogate w odniesienia historyczne, wyliczenia i interpretacje symboli heraldycznych.

Oto inne przykłady, tym razem znacznie bardziej skomplikowanego połączenia erudycji i enkomionu. W poniżej cytowanym wzorze mówca wykorzystuje poszczególne atrybuty wspomniane w egzemplum:

Wchodzące do domów oblubieńców swoich rzymskie oblubienice z zapalonymi pochodniami i weselnym okrzykiem wprowadzali, drogę im niejako pokazując. Przyznać to rodowitej podkowie Jej Mości Panny N., że ja nie pospolite pochodnie, ale jaśnie oświecone i prześwietne tytuły w dom Jego Mości Pana N. wprowadzają 28.

Zestawienie zasadza się na ogólnym podobieństwie sytuacji: zarówno rzymskiej,jak i polskiej narzeczonej wprowadzanej w dom męża towarzyszy światło. Poszczególnym elementom składowym opisu ceremonii nadaje się jednak wymiar symboliczny: drzewce umaczane w smole zastąpione zostają przez cnotę i slawę, urzędy i godności sprawowane przez krewnych i powinowatych panny młodej. które świecą blaskiem daleko silniejszym niż antyczne pochodnie. Rzymski dom

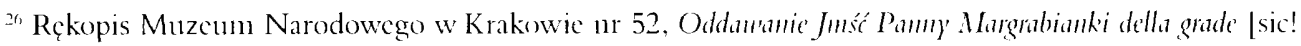

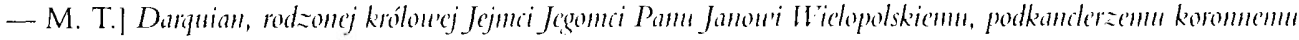

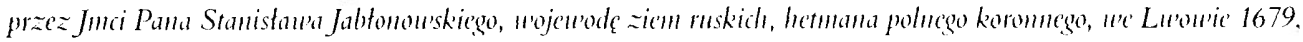
s. $135-143$.

${ }^{27}$ Ibidcm. S. 137

${ }^{2 k}$ Rps BUW 197, s. 262.
} 
rozumiany jako budynek mieszkalny staje się synonimem rodu szlacheckiego, zaś w miejsce panny młodej wprowadza się metonimiczny symbol heraldyczny calej jej rodziny — podkowę.

I kolejny przykład, jeszcze bardziej złożony:

Ponieważ oratorowie rzymscy małżeński stan coningum a ingo, to jest od jarzma, nazywali, dlatego że u Rzymian oblubieńcy i oblubienice przy ślubach swoich pod jarzmo podchodzili. A któraż większa może być figura tej rzymskiej ceremoniji, jako herbowny Jej Mości Panny krzyż, który Oblubieniec swego kościoła, Chrystus, słodkim jarzmem a letkim ciężarem nazwat ${ }^{29}$.

Mechanizm tu wykorzystany jest analogiczny: egzemplum zostaje przeinterpretowane w sposób symboliczny z wykorzystaniem podobieństwa obu sytuacji. Tu jednak przykład objaśnia się nie bezpośrednio, ale za pomocą dodatkowego odwolania się do tradycji ewangelicznej: jarzmo utożsamia się z krzyżem, do czego upoważniają słowa samego Chrystusa, zaś krzyż widniejący w herbie panny młodej staje się nośnikiem naddanych sensów powstałych w wyniku zestawienia tradycji antycznej i wartości chrześcijańskich. Oba egzempla same w sobie są przede wszystkim ciekawostkami obyczajowymi. Interpretacja nadaje im głębszy sens symboliczny, przez co stają się elementem składowym enkomionu.

Ostatni przykład ma jednak dodatkowe funkcje objaśniające - opisany obrzęd thumaczy pochodzenie stowa „coningum” od ,jarzma”. Podobną rolę odgrywają kolejne erudycje:

Rzymskie oblubienice w dzień wesela swego brały na się puram togam, to jest białą szatę, żadnym jeszcze kolorem nieznaczoną. Skąd do tego czasu zwyczaj u chrześcijan w białych albo w perłowych szatach do ślubu przychodzic ${ }^{30}$;

Tertulijan świadczy, że u wszystkich prawie narodów ten był zwyczaj, że nowożeńców koronowano, skąd się też sponsae reginae, sponsi reges nazywali, i w hebrajskim nxor znaczy regina ${ }^{31}$;

U Rzymian oblubienica, wchodząc w dom oblubieńca swego, mawiala: Ubi tu Caius, ego Caia, to jest: gdzieś ty Panem, ja Panią. Skąd do tego czasu mawiany podczas wesela: pan młody, pani młoda ${ }^{32}$.

W cytowanych tu fragmentach autor posuwa się do calkowicie nieuprawnionych interpretacji i podaje falszywe etymologie (tlumaczenie imion Caius i Caia jako „pan” i „pani”

2"Ibidem, s. 129: zob. Mt 11.30: .Albowiem jarzmo moje wdziçczne jest, a brzemiç moje lekkic" (tł. J. Wujek).

3"Ibidem, s. 79

${ }^{31} \mathrm{~S}$. Wysocki. op. cit.

${ }^{32}$ Rps BUW 197, s. 79. 
czy przewrotna konstatacja o znaczeniu „hebrajskiego" slowa „wiror”), jednak funkcja objaśniająca tekstu pozostaje niezmienna.

Takie zabiegi stosowane były dość często, czego najlepszym dowodem jest oracja Jakuba Sobieskiego, którą wygłosil w 1638 roku na weselu Eufrozyny Żanowskiej, kasztelanki tarnowskiej, i Jerzego Wiśniowieckiego, starosty kamionackiego. Sobieski, dziękując za pannę, dokonuje parafrazy rzymskiej formuly ceremonialnej:

Przypomnialen sobie foremną jednę u Rzymian przy pogańskich ich ślubachs ${ }^{3.3}$ ceremoniją, mawiała więc oblubienica oblubieńcowi swemu: Si tu Caius, ego Caia. Wzajem także oblubieniec jej mówil: Si tu Caia, ego Cains. Chcieli, widzę, w tych słowach wyrazić paritatem obojga w małżéstwie, co się też tu właśnie dzieje.

Subtelne zafalszowanie, czy też może raczej reinterpretacja kwestii wypowiadanej przez narzeczonych sluży bardzo konkretnemu celowi: wykazaniu równości państwa młodych. Mówca objaśnia więc formulę, ale jedynie tę sparafrazowaną na własny uży tek. Fraza, która miała początkowo wyrażać obietnicę wierności i oddania, dzięki zmianie ..ubi” na „si” staje się nośnikiem nowych znaczeń. Kwestią podstawową przy zawieraniu malżeństwa w dobie staropolskiej byla równość narzeczonych pod względem stanu, urodzenia, koligacji i majątku ${ }^{3+}$. Mówcy oddający pannę i dziçkujący za nią clıwalili rody państwa młodych, aby pozyskać dla jednej i drugiej strony wzajemny szacunck - enkomion zawarty w dziękowaniu winien się równać pochwale wygłoszonej w oddawaniu. Swoisty dialog, który odbywal się między tymi oratorami, nie miał w zamierzeniu stanowić wyścigu panegirycznego, ale osiągnąć stan równowagi. gdyż tylkow ten sposób ową paritas można bylo ukazać35

\footnotetext{
33 Poprawka autorki: w rpsic: „slużbach".

${ }^{3+}$ Najwyraźnicj pisal o tym w XVI wicku Mikolaj Rej: „A jesli juześ tak na tym swą myśl postanowil. iz w tym poczciwym stanie checsz żywot swój postanowić a staniku swego ponicrnego. poważnego, statecznego i bogobojnego użyć, szukajż żonki staniku sobic równego. wychowania a ćwiczenia roztropnego, obyczajów nadobnych a wstydliwych. a ponocy wżdy jakicj. jaka może być. bo powicdają. iż to są przysmaki do dobrego ożcnicnia: uroda, obyczajc, przyjacicle a pomoc [posag - M. T.]. (...) A tan ci już Pan Bóg pozdarzy wedle obietnic swoich. że z onym milym a wdziçcznym a sobic równym towarzyszen swoim używiesz dhugo rozkosznego żywota swego i wszytkoć się sporzyé i munożyé bçdzic okolo cicbie. jako ono powiadają. jako wianki wil. Bo co jest po dlugim żywocic, jeśli nic będzic wdzięczncgo a mitego

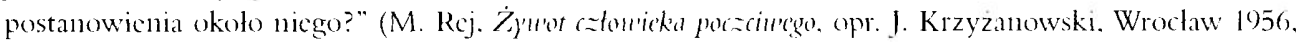
BN I 152, s. 116-117).

${ }^{35}$ Nic zawsze ta równowaga byla osiagana i nic zawsze jej osiągnięcic było celem mówców. Odpowiedzią na cytowaną tu mowę Stanisława Jabłonowskiego, której tckst składa sį̣ głównic z wyjątkowo precyzyjnego opisu koligacji z rodziną królewską każdej z galçzi rodu i interpretacji symboli sześciu herbów panny mlodej, byla mowa Stanislaw I Icrakliusza Lubomirskiego zawierająca zredukowaną do kilku zaledwic

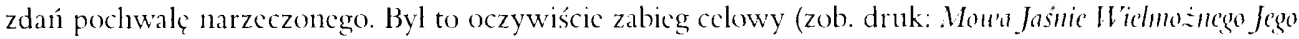

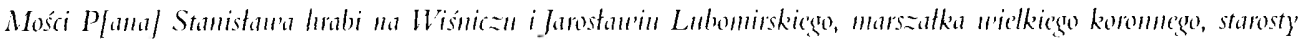

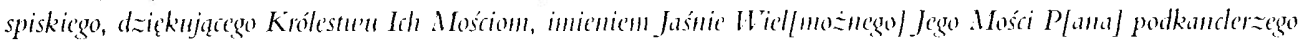

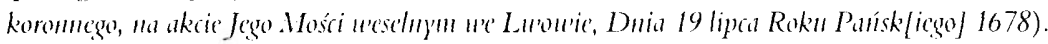


Egzempla dobiera się na zasadzie podobieństwa całkowitego (exemplum simile), różnicy (exemplum dissimile) lub przeciwieństwa (exemplum contrarium $)^{36}$. Do grupy przykładów podobnych lub różniących się w niewielkim stopniu należą wszystkie te opisywane zwyczaje weselne, które w pewnym stopniu przypominają tradycję polską, a zatem: wymiana pierścionków, koronowanie wieńcami, podawanie kielichów z winem lub wodą itd. Przywolanie takiej starożytnej ceremonii wskazuje na więź międ zy świetną kulturą antyczną i współczesną kulturą szlachecką, i stanowi niezaprzeczalny dowód ciąglości tradycji oraz faktu, że to Rzeczpospolita jest tej tradycji wierną kontynuatorką. Podanie antycznej genezy danego zwyczaju nie tyle go nobilituje, co raczej potwierdza jego wyjątkową wartość, zwłaszcza że kategoria starożytności cieszyła się powszechnym uzıaniem, by nie rzec prestiżem.

Jeden zXVII-wiecznych mówców widzi wakcie ofiarowania pannie wieńca swoistą kontynuację greckiej ceremonii nagradzania zwycięzców zawodów sportowych:

Zwyczaj ten byl u Lacedemończyków, moja Miłościwa Panno, że mlodzieńcom panny wieńce oddawały tym, którzy zaciągi i zawody pewne dla dostapienia sławy i dla otrzymania łaski na naznaczonych placach i terminach odprawowali, a który prędszym biegiem pierwej do miejsca naznaczonego dobieżał, każda więc swego patrzając, tam znak zwycięstwa i wygranej przyjaźni wieńcem obsyłała. Owo zgoła wieniec zawsze znaczyl pewne szczęście i pociechy, i w rozmaitych szwankach za palmę zawsze uchodzil. U nas ojczystym sposobem mlodzieńcy pannom zwykli wieńce oddawać, które znakiem są panieńskiej czystości i dostojności ${ }^{37}$.

Orator podkreśla, że wspólcześnie oddawany wieniec ma bogatszą symbolikę, jednak taka interpretacja i wskazanie zależności między obrzędami musiała przypaść do gustu ówczesnym czytelnikom, gdyż tekst ten był jednym z najczęściej kopiowanych wzorów mowy weselnej w pierwszej połowie XVII stulecia ${ }^{38}$. W innym wzorze retorycznym, stosownym do wykorzystania przy oddawaniu naszyjnika, czytamy, że Rzymianie i Grecy mieli zwyczaj ofiarowywania zwycięskim żołnierzom złotych lańcuchów w dowód uznania ich odwagi i męstwa. Indukcja została tu przeprowadzona z wykorzystaniem echa toposu „miłość - walką":

\footnotetext{
3t Zob. H. Lausberg, Retoryka literacka. Podstan'y uredzy o literaturze, th. i opr. A. Gorzkowski. Bydgoszcz 20(12, s. 255-257; T. Szostck. Funkcjonouranic egze'mplum.... op. cit., s. 50.

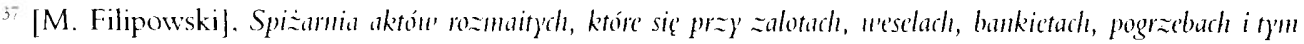

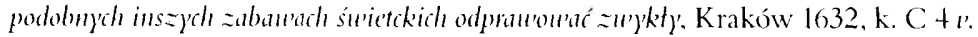

${ }^{3 \wedge}$ Tekst tej mowy znajduje siç miçdzy innymi we rpsach: BCzart., s. 97-98; Ossol. 207. k. 301-301 ı.; Ossol. 197. k. 1t-1+1': Biblioteki Kórnickicj sygn. BK 1195, k. 119 1': d. Bibliotcki Ordynacji Zamojskicj (obecnie w Bibliotece Narodowej w Warszawic) sygn. BN BOZ 823, s. 206-2(1); BUW 50), k. 272 1:-273.
} 
Obrzçd rzymski, perski, portugalski, celtycki... i sarmacki. Kultury obce w historycznych egzemplach... 105

Uznawa i Jegomość Miłościwy Pan zwyciężonym się być życzliwością Waszmość Miłościwej Panny, i dlatego na znak zwycięstwa tego, te łańcuchy Waszmość Miłościwej Pannie ofiaruje przez mię, sługę i przyjaciela swego (... $)^{39}$.

W polskiej literaturze przedmiotu egzemplum najczęściej omawiane było w kontekście sztuki kaznodziejskiej, a jako takie mialo przede wszystkim charakter parenetyczny ${ }^{+()}$. Funkcja dydaktyczna, perswazyjna, dominowala zatem nad retorycznym delectare, a sprawienie przyjemności odbiorcy stawało tylko środkiem do osiągnięcia wlaściwego celu ${ }^{+1}$. Piotr Skarga wysoko ocenial jego skuteczność oddziaływania na odbiorcę, w myśl zasady , werba docent, exempla tralmunt” pisząc: „Przykłady są jako niema retoryka, które bez mowy będąc, tak mówią, iż namówią" . Tymczasem gemus demonstratio'tum, do którego należą oracje weselne, z zasady i istoty swej najdalsze jest od pouczania, przekonywania czy namawiania, a jednak na równi ze sztuką kaznodziejską korzysta z dobrodziejstw przykładów i erudycji. Także rola egzemplum jest tu nieco odmienna niż ta, którą odgrywato w kazaniach. Przykład w oracji weselnej (i ogólnie w rodzaju pokazującym) nie był ukierunkowany na przyszłość, w tym sensie, w jakim mial oddziałać na postawę moralną słuchacza, będącą skutkiem perswazji kaznodziejskiej, ale na teraźniejszość - stanowil jedynie dodatkowe objaśnienie kwestii niespornej, ozdobnik pozbawiony moralizacji, rodzaj komentarza do slów mówcy, nie zaś argument. Jednak pierwszorzędnym celem użycia egzemplım bylo zaciekawienia słuchacza i sprawienie mu intelektualncj przyjemności. rozumianej tu także między innymi jako potwierdzenie wysokiej wartości kultury, której słuchacz jest uczestnikiem. Atrakcyjność wykorzystywanych opisów zwyczajów zasadzała się głównie na subiektywnym odczuciu ich egzotyczności, traktowanej jako odmienność kulturowa, obcość i niezwyktość. ${ }^{43} \mathrm{~W}$ mowach wspominano bowiem nie tylko Rzymian i Greków, których historia i kultura byla dobrze znana szerszym kręgom szlachty i jako taka

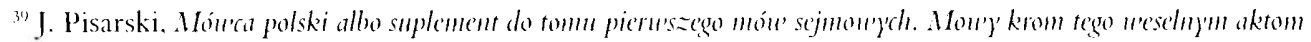

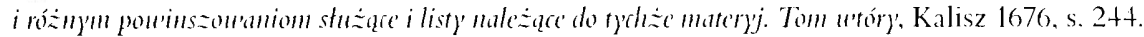

+"..... exemphum oznacza formę wypowicdzi narracyjncj o różncj dlugości, w tym także samo wspomnicnie zdarzeń osób, tak fikcyjnych, jak i historycznych. oraz sytuacji związanych ze światem przyrody. Przywolane zostaje w celach przede wszystkim dydaktycznych: dla ukazania pożądancgo wzorca postaw ludzkich lub też jego odstraszającej od naśladownictwa antytczy." (T. Szostck. Excmulum " polskim śrédniouice $\approx$, Warszawa 1997, s. 13: o cgzcmplacl w sztuce kaznodzicjskicj zob.: M. Adamczyk. Egzemplum. haslo w: Ston'mik literatury staropolskicj (średnioniecze - renesuns - burok). red. T. Michalowska, Wroclaw

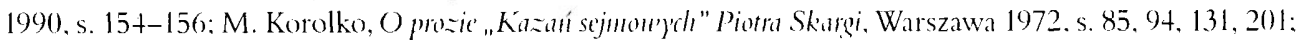

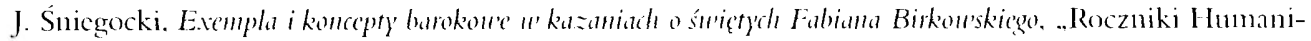
styczne" t. 27: 1970. z. 1, s. 109-135: B. Geremek, Excmplmn i preckas kultury), w: Kultura cliturma a kultura masou'd u' Polsce póśnego średmioniecezr. red. B. Geremek. Wroclaw 1978, s. 53-76).

+' O „rckreacyjncj” funkcji cgzemplów w kazaniach barokowych jako sposobie zajęcia uwagi odbiorcy zob. m. in. J. Śniegocki, op. cit., s. 111,113-114.

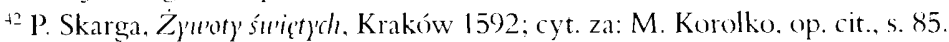

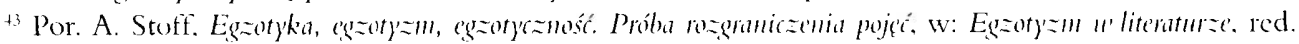

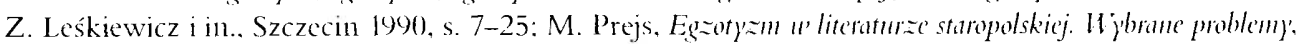
Warszawa 1999, s. 5-9. 
nie była uznawana za egzotyczną, ale przywoływano również starożytne cywilizacje Egipcjan, Elamitów, Galów, Hebrajczyków, Asyryjczyków, nawet Scytów, a także całkiem nowożytne narody: Francuzów, Anglików czy Portugalczyków. Mówiąc o odczuciu niezwykłości opisywanych ceremonii i wymienianych nacji, pamiętać należy, że oracje weselne miały charakter wyjątkowo egalitarny, i wygłaszane były zarówno w magnackich zamkach, jak i w szlacheckich dworkach. Rzeczą oczywistą jest więc, że to, co bylo postrzegane jako egzotyczne w mazowieckim zaciszu, niekoniecznie wydawało się równie atrakcyjne gościom zgromadzonym na weselu jednej z dwórek królewskich. Dodajmy też, że przynajmniej połowę weselnego audytorium stanowiły znacznie słabiej wykształcone i mniej obyte w świecie kobiety, których zadziwienie lub nawet zaszokowanie egzotycznymi opowieściami nie stanowilo większego wyzwania.

Przytoczmy jeszcze kilka erıdycji, które pokażą, jak na weselach „szokowano” shuchaczy:

U Franków podczas weselnych aktów oblubieńcy wzajemnie żelazem rozpalonym na czołach charakter albo litery sobie wyrażalit+;

U Indów [młodzieńcowi nie godziło się żenić - przyp. M. T.], któryby w potyczkach adwersanta nie zwyciężyt ${ }^{+5}$;

U Anglików oblubienicę koronują cierniem, a w ręce drugiej wieniec trzymają ${ }^{+6}$;

U Karmanów żaden nie mógł się starać o dożywotnią przyjaźn, któryby królowi glowej nieprzyjacielskiej nie przynióst ${ }^{+7}$;

Megarejczycy narzeczonych przed złączeniem uderzaja pięściami od przedsionka świątyni aż do ottarza, pokazując, że nikt nie dochodzi do radości, chyba że przez walkę z przeciwnikiem ${ }^{++}$;

U Gotów, gdy kaplan podawal pobłogoslawiony pierścień stojącym, uderzali oni narzeczonych w policzki+";

W Beocji narzeczoną wieńczono szparagiem, jak podaje Plutarch. 1)zieje się tak dla pokazania, że związek na całe życie jest szlachetny i przyjemny. Albowiem szparag, jak się uważa, wydaje slodki owoc z bardzo gorzkiego ciemia ${ }^{50}$;

U Kohów narzeczony, mający zamiar się zaręczyć, ubieral się w szatę kobiecą̧51.

\footnotetext{
${ }^{+t}$ Rps BUW 197. s. 89.

t5 S. Wysocki, op. cit.

+t Rps BUW 197, s. 8.3.

+7 Ibidem, s. 78: na marginesie dowcipny dopisek: .. Bez prace nie będa kulacze".

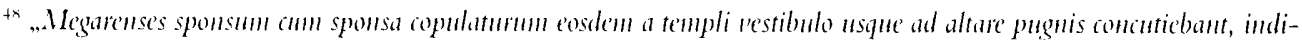
cantes meminem ad gandia pervenié misi per tollerantiam adersonm" - rps BCzart. 1884, s. 13.

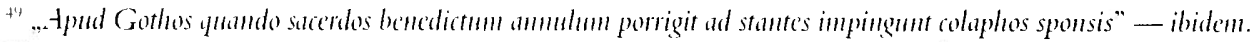

5" "In Beotia sponsam aspanagine conomant, at agit Plutardhus. Fit antem id ad significandum arbanam incaundamque l'itac societatem, mam asparagns, ut dicitur, fundit smanem fructum ex spima asperrima" - ibiden, s. 10.

"..tpud Colles sponsus sponsolia initurus muliebri neste induitur" - ibidem, s. 12.
} 
Zwyczaje wzajemnego piętnowania się nowożeńców, koronowania panny mołodej cierniem czy policzkowania narzeczonych jawią się jako okrutne i harbarzyı́skie. Uwodzą co prawda niezwykłością, mają posmak sensacji, jednak odczucia, które budzą, są przede wszystkim negatywne. Podobnie przebieranie się w suknic kobiece czy odbywanie połogu w zastępstwie żony może budzić co najwyżej śmiech i niedowierzanie. W zestawieniu z takimi opisami staropolski obrzęd weselny zyskuje na wartości jako prawdziwie cywilizowany, co z kolei gloryfikıje całą kulturę szlachecka, o wyższości której każdy sarmata żywił głębokie przekonanie, i do czego zasadniczo nie trzeba go było przekonywać ${ }^{52}$.

Niektórzy oratorzy szczególnie pilnie przykładali się do swego zadania. Ponizszy fragment wstępu mowy przy oddawaniu upominków pannie młodej znakomicie to ilustruje:

Jest przypowieść pospolita: co kraj, to obyczaj N. etc. [np. Moi Mitościwi Państwo - przyp. M. T.] U Persów dziatek do lat czterech po porodzeniu widzieć się nie godzi. U Gordyjów takich królem obierają, którzy nacielistszy. U Syranów tego koronuja, który jest nawyższy. Tybanowie po połogu żon swoich jakoby polożnicy, związawszy sobie głowy, sami połóg wylegają. Synodes ojców swoich zjadają, wyjąwszy głowy, które pozlacają. Tysselowie kości bogom ofiarıją, a sami mięso zjadają. Owa, co kraj, to obyczaj ${ }^{53}$.

Trudno orzec, który z wymienionych tu zwyczajów miał być w zamiarze mówcy najbardziej egzotyczny i szokujący, najważniejsze jest jednak jednoznaczne przeciwstawienie „barbarzyńskim” ceremoniom weselnych obrzędów rzymskich i polskich. W dalszej bowiem części oracji oddający upominek wspomina zwyczaj ofiarowania rzymskiej oblıbienicy płonącej pochodni, zaś egipskicj panie młodej - wody w roztruchanie, po czym dodaje:

Polacy i Litwa jakow inszych sprawach dzielni, takze i w tym akcie nowej oblıbienicy wszelką uczciwość i winszowanie z drogimi klejnotami, choć bez ognia materyjahnego oddawają. Nie bez ognia jednak przyjacielskiej miłości... ${ }^{5+}$

Nie tylko okrucieństwo czy śmieszność obrzędu stanowiło o niższości ceremonii obcych narodów wobec tradycji rodzimej. Także sam fakt, że były to zwyczaje poganískie, sta-

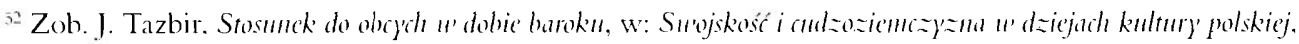
red. Z. Stefanowska, Warszawa 1973, s. 80-112; J. Michalski, Sarmaty=m a curopeizacja Polski un NT Ill u'ieku, w: op. cit., s. $11+-117$.

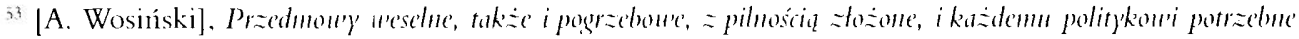
i poźzteczlle, Kraków 1633, k. A 2.

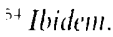


wał się często argumentem dewaluującym ich wartość. Tak wlaśnie rozumuje autor kolejnej cytowanej tu mowy weselnej:

Świadczą o tym slawnych historyków pisma, WMMP, że Asyryjczykowie tej ceremonijej przy weselnych sprawach zażywać zwykli: tegoż dnia po poślubieniu zobopólnym abo też nazajutrz przed wschodem słońca na łąki przestrone wychadzali. Tam potym pan mody uczyniwszy pokłon słońcu, zalecenie także rodziców swych wdzięcznie przyjąwszy, obracał się do słońca wschodzącego, czyniąc przysięgę malżonce swej dopiero poślubionej, wiary aże do ostatniej żywota swego godziny nierozerwanie dotrzymać miał. To poganie ${ }^{53}$.

Przedstawiona tu ceremonia jest de facto bardzo piękna, jednak orator, który opisuje ją tak szczególowo, nie znajdıje dla niej uznania. Przysięgę małżeńską, według niego, godzi się skladać jedynie w świątyni chrześcijańskiej i w obecności sługi prawdziwego Boga. Po niemal lekceważącej konstatacji „To poganie”, mówca zdecydowanie odcina się od bałwochwalczych praktyk asyryjskich.

Istotne jest, że żadnemu z narodów wspominanych w oracjach weselnych nie przypisano stalych cech, atrybutów, sklonności czy preferencji, które mogłyby się wyrażać i znaleźć odzwierciedlenie w obyczaju. W popularnych w omawianym okresie publikacjach typu Descriptio gentium, Nationum properietates czy Icon animormm przedstawiano członków poszczególnych nacji jako nosicieli jednej głównej lub kilku cech narodowych, które zdominowały wszystkie pozostałe ${ }^{56}$. I Hiszpan mial być zatem nadęty i śmiały, Wloch dowcipny, pyszny i mściwy, Niemiec zapalczywy, Polak dworny i leniwy ${ }^{57}$. Jednak omawiane erudycje nie wykazuja tendencji do takiej redukcji i jednoznaczności. Anglicy bywają okrutni, gdy każą pannie młodej nosić koronę cierniową, i całkiem cywilizowani, gdy, jak podaje inny przykład, ozdabiająją wieńcem klosianym. Co więcej, ponieważ w oracjach weselnych wykorzystuje się najczęściej opisy obrzędów, z których większość jest wspólna całej cywilizacji europejskiej, czasami nazwy narodów lub plemion stają się etykietami, które można wymicnić na imne bez szkody dla samego egzemplum. W tej sytuacji mówcę i słuchacza interesuje tylko wykazanic podobieństwa albo jednoznacznej wyższości polskiej kultury szlacheckiej nad każdą inną. Dodajmy, że to samo egzemplum może w jednej mowie funkcjonować jako simile, a w innej jako contrarium. Cytowana tu już erudycja dotycząca Karmanów, którzy nie mogli zawierać związków małżéskich, dopóki nie ofiarowali swemu królowi głowy nieprzyjaciela, może być interpretowana na dwa różne sposoby. Badacz oratorstwa

[M. Filipowski]. op. cit.. k. D 2.

5t Zub. J. Tazbir. Szlaki kultury polskicj. Warszawa 1986, s. 9-12.

5 Zob. S. Kot. Nutionum Proprictutes, .. Oxford Slavonic Papers” 1955, s. 8. za: J. Tazbir, Szlaki kultury polskicj.... op. cit.. s. 9. 
weselnego z łatwością umie wyobrazić sobie sytuację, gdy mówca wykorzystuje ten przykład w enkomionie kawalera, który w sposób szczególny zasłużył się na polı bitwy, a teraz wraca w glorii i clıwale, aby założyć rodzinę i osiąść w rodowym gnieździe. Opis zwyczaju Karmanów stanie się wówczas éxémplum simile i potwierdzi prawo mlodzieńca do ubiegania się o rękę panny. W takim kontekście Karmanowie będą jawić się jako naród dzielny i mężny. Jednak ten sam opis może stać się exemplum contrurium, jeśli orator wkomponuje go na przykład w pochwalę panny, wykazıjąc, że nic żąda ona krwawych ofiar wzorem barbarzyńskich wladców, i w swej roztropności i lagodności najwyższą wartość znajduje w szczerym afekcie narzeczonego. Tak interpretowany ten sam zwyczaj czyni z Karmanów okrutników i niemal morderców. Ocena narodı, jego obyczajowości i kultury zależy zatem w duzej mierze od inwencji mówcy, nie zaś od treści przykładı.

O ile opinia o obcych nacjach może być różna, to rzeczą nicpodlegającą dyskusji ani reinterpretacji jest uznany fakt, że żadna cywilizacja nie wykształciła tak pięknej ceremonii weselnej jak polska i szlachecka. Taki właśnie tok rozumowania przedstawia autor następnej mowy:

Różne narody, mój Miłościwy Panie, różne postçpki przy zobopólnym zjednoczeniu zachowywać zwykły, aby tak cnymi powierzchnymi ceremonijami swymi jako przeszłą, tak przyszłą i już zawartą miłość, zgodę, uprzejmość i jedność potwierdzić mogły. Dziwne akta nam wspominaja historyje [z] strony Greków, z strony Rzymianów i inszych nam odleglych narodów, w których rozmaite ich postępki i ceremonije przy odprawowaniu aktu weselnego wspominają. Wiem, że Waszmości mnic Milościwemu Panu nie są tajne. Ja historyjej na ten [raz] opiewać nie chcę i tegoż żadnej przyczyny nie widzę. Rozumiem jednak, że nie od rzeczy pospólstwo mówi: każdy kraj ma swój wlasny obyczaj ${ }^{58}$.

Orator nie czyni gwaltownych ataków na inne narody, przeciwnie, wydaje się nawet dopuszczać możliwość istnienia odmiennych niż polskie zwyczajów. Jego stosunek do kwestii różnic kulturowych jest obojętny, a w każdym razie nie widzi on realnej potrzeby emocjonowania się nimi, gdyż są one nicistotne w obliczu tak oczywistej i niewymagającej dalszych dowodów doskonałości polskiej weselncj tradycji retorycznej. I tak, „od Greków odstąpiwszy, Rzymianów zaniechawszy”, przechodzi do objaśniania słuchaczom genezy enkomionu rodowego, czyli najbardziej charakterystycznego komponentu oracji wyglaszanej przy oddawaniu panny.

Inny mówca opisıje z niezwykłym zacięcicm i szczegółowością rzymskie wróżby weselne ${ }^{5 \%}$. Oto bowiem w dniu planowanego ślubu „wieszczkowie” przyglądali się niebu.

${ }^{3 \times}$ [M. Filipowski]. op. cit., k. E: uzup. tekstu w klamrach - M. T.

j" J. Pisarski. op. cit.. s. 224. 
Silny wiatr i deszcz byly złym znakiem i ceremonię przekladano, natomiast ,zloty Febus jaśnicjącymi promieniami swymi do wesela wszytko na świecie pobudzal". Przemawiąący odrzuca te „superstycyje”, bowiem dla chrześcijanina każdy dzień, w którym dwoje szanujących się wzajemnie ludzi chce połączyć się świętym węzlem małżeńskim, jest dniem do tego celu nadającym się najlepiej - niezależnie od pogody.

I Iistoryczne egzemplum obyczajowe jest jednym z ciekawszych ozdobników wykorzystywanych w XVII- i XVIII-wiecznym oratorstwie weselnym. W przeciwieństwie do pozostałych typów erudycji pozwala obserwować cała gamę różnorakich emocji słuchaczy: od zdziwienia, zaszokowania, oburzenia i niedowierzania, do utwierdzenia się w poczuciu wartości wlasncj kultury, czyli samozadowolenia, a nawet „zachłyśnięcia się” nią. Przyklad, który w mowie weselnej może znaleźć zastosowanie w każdej części: we wstępie, pochwale, czy w kończących orację życzeniach, pełni przede wszystkim funkcję delectare, nie nakłania do polepszenia obyczaju, ale do zachowania go takim, jakim on jest w kształcie obecnym - czyli najdoskonalszym. 